\title{
Wound Healing Activity of $80 \%$ Methanol Leaf Extract of Zehneria scabra (L.f) Sond (Cucurbitaceae) in Mice
}

\author{
Bezu Tekleyes' \\ Solomon Assefa Huluka' \\ Kebede Wondu ${ }^{2}$ \\ Yohannes Tsegyie Wondmkun' \\ 'Department of Pharmacology and \\ Clinical Pharmacy, School of Pharmacy, \\ College of Health Sciences, Addis Ababa \\ University, Addis Ababa, Ethiopia; \\ ${ }^{2}$ Department of Pharmaceutics and Social \\ Pharmacy, School of Pharmacy, College of \\ Health Sciences, Addis Ababa University, \\ Addis Ababa, Ethiopia
}

Background: Zehneria scabra is one of the folklore plants of Ethiopia frequently used for external wound treatment in humans. Nevertheless, pharmacological investigations have not been performed to substantiate activity of the plant extract in wound healing. Hence, this study attempted to explore the activity of leaf extract of $Z$. scabra in wound healing using a mice model.

Materials and Methods: The air-dried leaf from Z. scabra was pulverized and extracted with $80 \%$ methanol and prepared with $5 \%$ and $10 \%$ extract ointments. An acute dermal toxicity study of the extract was conducted in female mice by observing the signs of toxicity. Then $5 \%$ and $10 \%(\mathrm{w} / \mathrm{w})$ ointments of the extract were applied topically to investigate their wound healing activity in incision and excision wound models. Parameters such as wound contraction, period of epithelialization, and tensile strength were determined.

Results: Upon the application of $10 \% \mathrm{w} / \mathrm{w}$ extract ointment, no signs of dermal toxicity were observed in mice. Both $5 \%$ and $10 \%(\mathrm{w} / \mathrm{w})$ extract ointment formulations increased percentage wound contraction and tensile strength, and shortened the epithelialization period. Conclusion: The findings of this study collectively showed that the leaf extract of $Z$. scabra possessed significant wound healing activity, upholding the folkloric use of the experimental plant. Keywords: Zehneria scabra, wound healing activity, incision model, excision model

\section{Introduction}

A wound is characterized as damage of the normal anatomy and function of the skin. ${ }^{1}$ This may vary from a minor injury of epithelial tissues of the skin or maybe deeper damage to the subcutaneous tissue and others like blood vessels, muscles, tendons, bones, parenchymal organs, and nerves. ${ }^{1}$ Wounds may be caused by pathological changes that start internally or externally from the involved organ. They may have an intentional or accidental etiology or may be the effect of a process of disease. ${ }^{2}$ The physiological reaction to the damaging factor results in bleeding, coagulation of the vessel, complement activation, and inflammatory response. ${ }^{2}$ Wound is one of the most common diseases often having severe complications in relation to health and posing high costs for therapy. To establish the integrity of the damaged tissue, the series of events must be progressed orderly in a well-controlled manner that, otherwise maybe causing physical disability even leading to death. ${ }^{3}$ Currently available methods of wound management including irrigation, debridement, antibiotics, proteolytic enzymes and tissue grafts are found to be associated with major drawbacks such as invasiveness and are expensive. ${ }^{4}$

\footnotetext{
Correspondence: Yohannes Tsegyie Wondmkun

Department of Pharmacology and Clinica Pharmacy, School of Pharmacy, College of Health Sciences, Addis Ababa University, Churchill Avenue P.O. Box II76, Addis Ababa, Ethiopia

Email yonitse2015@gmail.com
} 
Emergence of resistant strains along with lack, high cost and retarded rate of newly generated antibiotics increase wound related mortality and morbidity. ${ }^{5}$ Globally, the emergence of resistant bacteria strains mostly those wound causing bacteria is a public health crisis. Multidrug resistant Pseudomonas and Acinetobacter species, vancomycin resistant Staphylococcus aureus (VRSA), and methicillin resistant Staphylococcus aureus (MRSA) are some examples. ${ }^{6}$ As a result, infection of a wound is continuing as the most common influencing factor of nonhealing wounds existence and remains a significant burden for patients and caregivers alike. Different studies are being made across the world to uncover agents that can facilitate healing and thereby minimize hospitalization costs and save the patient from amputation or other serious complications. However, the holistic management and current medicine for treating chronic wounds is very expensive. ${ }^{7}$ The global advanced wound management market, estimated at $\$ 20$ billion, is projected to rise at a combined annual growth rate of around $7 \%$ to around \$26 billion. ${ }^{8}$ In England, the National Health Service described the cost incurred for wound treatment as between $£ 2.5$ billion and $£ 3.1$ billion per year, accounting for $3-4 \%$ of the healthcare budget. ${ }^{8}$ Most of the drugs employed in wound treatment are not only costly but also have issues such as hypersensitivity reaction and drug resistance. In addition, among the drugs listed in Western Pharmacopoeia only $1-3 \%$ of them are recommended to be used on the skin and wounds; however, approximately one third of herbal medicines are intended for such use. ${ }^{9}$

Phytomedicines for wound healing are also needed to resolve costs, adverse effects, and antibiotic resistance. ${ }^{9}$ However, scientific confirmation, standardization, and safety assessment of plants used in conventional medicines before they could be recommended for wound healing are needed. The leaves of $Z$. scabra are used traditionally for wound dressing and healing, treatment of helminthic disease, body swelling, and diarrhea. ${ }^{10}$ Roots and leaves are also used to manage fever, common cold, skin problems and stomach pain. On top of this, a recent study confirms the ethanol and ethyl acetate shoot extract of $Z$. scabra have antimicrobial activity against the most common bacterial pathogens, ie, Staphylococcus aureus and E. coli. ${ }^{11}$ The ethanolic tuber extract was also proved to have potent antifungal properties against five types of fungi including A. niger, A. flavus, A. fumigatus, $M$. indicus, and $C$. albicans. In addition, the $80 \%$ methanolic leaves of extract have been proven to have anti-diarrheal and anti-secretary, ${ }^{12}$ anti-malarial, ${ }^{13}$ and anti- inflammatory activities. ${ }^{14}$ The present experimental plant is traditionally claimed to have wound healing activity, which needs scientific investigation.

\section{Materials and Methods Chemicals, Drugs, and Solvents}

Methanol (Carlo Erba Reagents, Italy), ketamine hydrochloride (Neon laboratories, India), diazepam (Gland Pharma limited, India), nitrofurazone USP $0.2 \%$ ointment (Shanghai General Pharmaceutical co, Ltd, China), wool fat, hard paraffin, white soft paraffin (queens Hygore industrie Plc), and cetostearyl alcohol (Banbury, Oxon, UK) were used. All chemicals and reagents used were of analytical grade.

\section{Plant Material}

Fresh leaves of $Z$ scabra were obtained from the College of Health Science, Tikur Anbessa Specialized Hospital compound from February 15-20, 2020. The plant material has been identified and verified by a taxonomist and a voucher specimen (MWBZ-025) was deposited at the National Herbarium of College of Natural and Computational Sciences, Addis Ababa University for future reference.

\section{Experimental Animals}

Adult albino mice of both sexes $(25-35 \mathrm{~g}$, and 6-8 weeks of age) were obtained from the animal house of School of Pharmacy, College of Health Sciences, Addis Ababa University. The mice were randomly kept in groups of 4 and $5(n=5)$ in clean cages with a wire mesh top containing a hygienic bed of sawdust (regularly changed every 3 days) and retained in a well-ventilated room $\left(25 \pm 1^{\circ} \mathrm{C}\right.$ with $55 \pm 5 \%$ humidity) for excision and incision wound models, respectively. Then the mice were acclimatized with the environment for a week before the initiation of the experiment. All procedures were conducted according to the standard guidelines for the care and use of laboratory animals. ${ }^{15}$ The experimental protocol was approved by the Institutional Review Board of School of Pharmacy, College of Health Sciences, Addis Ababa University (ERB/SOP/151/03/2020).

\section{Plant Extraction}

The Leaves of $Z$. scabra were dried and pulverized using a mortar and pestle to get a fine powder that could be extracted. A portion of $Z$. scabra leaf powder sample was weighed (1 kg) and macerated in $80 \%$ methanol (1:5) for 3 
consecutive days at room temperature using a conical flask with occasional shaking. The macerated plant material was then filtered by Whatman filter paper. The residue was remacerated in $80 \%$ methanol for the second time for another 3 days to fully extract the plant material and then filtered. The filtrates were collected and concentrated using a Rota vapor at temperature of $45^{\circ} \mathrm{C}$ to get rid of the organic solvent. Concentrated extract was then frozen in a deep freezer and dried in a lyophilizer to remove the aqueous content. At last, the dried crude extract was stored in a closed container and kept in a refrigerator for the preparation of ointment formulations.

\section{Percentage Yield of the Crude Extract}

The weight of crude extract was measured and the percentage yield was calculated per weight of the sample. The yield (\%) of dried extract was determined by Eq. 1.

$$
\text { Percentage yield }=\frac{\text { weight of extract }}{\text { weight of sample }} \times 100 \text { (1) }
$$

\section{Formulation of Extract Ointment and Simple Ointment}

Simple ointment was formulated using white $170 \mathrm{~g}$ white soft paraffin, $10 \mathrm{~g}$ hard paraffin, $10 \mathrm{~g}$ cetostearyl alcohol, and $10 \mathrm{~g}$ wool fat in accordance with the British Pharmacopoeia (BP, 1988a) following the formula. ${ }^{16}$ All the constituents of the ointment base were mixed and gently heated, stirring until homogeneous and cold ointment was obtained.

The extract ointment was prepared in different concentrations, ie, in $5 \%(\mathrm{w} / \mathrm{w})$ ointment $(5 \mathrm{~g}$ of crude extract was mixed with $95 \mathrm{~g}$ of ointment base B.P) and in $10 \%$ $(\mathrm{w} / \mathrm{w})$ ointment $(10 \mathrm{~g}$ of extract was added in $90 \mathrm{~g}$ of ointment base B.P). ${ }^{17}$ To compare wound healing potential of the extract, nitrofurazone ointment $(0.2 \% \mathrm{w} / \mathrm{w} \mathrm{NF})$ was used as a standard drug.

\section{Grouping and Dosing}

For the excision model the mice were randomly assigned into four groups ( $\mathrm{n}=5)$ as follows: Group I mice were treated with a simple ointment base (negative control). Group II and III mice were topically treated with $5 \% \mathrm{w} / \mathrm{w}$ and $10 \% \mathrm{w} / \mathrm{w}$ of extract ointment preparations, respectively; group IV (positive control) mice were treated with $0.2 \% \mathrm{w} / \mathrm{w}$ NF. For incision model the animals were assigned into five groups $(\mathrm{n}=5)$ including the untreated group. ${ }^{18}$

\section{Acute Dermal Toxicity Study}

The acute dermal toxicity test of the crude extract of Z. scabra was carried out as per OECD draft guideline number $404{ }^{18}$ Three female mice having normal skin surface were randomly selected and maintained in a cage individually and acclimatized to the working environment for a week prior to the commencement of the test. Around $10 \%$ of the body surface area fur was shaved from the dorsal area of the trunk 24 hours prior to study. $10 \% \mathrm{w} / \mathrm{w}$ of the extract formulation was uniformly applied over the shaved area for 24 hours. Mice were housed individually during the exposure period.

The residual test substance was removed at the end of the exposure period and the mice were observed daily for any adverse skin reactions for 14 days. ${ }^{18}$

\section{Wound Healing Models}

In the present study to evaluate the wound-healing activity of the leaf extract of Z. scabra excision and incision wound models were used.

\section{Excision Wound Model}

Animals have been anesthetized with intraperitoneal injection of ketamine $(1 \mathrm{~mL} / \mathrm{kg})$ and diazepam $(1 \mathrm{~mL} / \mathrm{kg})$ and the back hair of the animals has been shaved. After this, approximately $300 \mathrm{~mm}^{2}$ circular areas were marked and the full thickness of this area was removed by the use of sharp sterilized scissors. Twenty-four hours after wound formation, the preparations were applied topically once daily for each group based on the respective grouping as explained in the grouping and dosing section, to cover the wound surface till complete healing was achieved. The wound closure rate was assessed by tracking the wound on each alternate day post-wounding using transparent paper and a permanent marker. The wound diameters were measured until the wound was fully closed and the areas calculated. The wound was left uncovered in the open environment, after which the wound contraction and the period of epithelization were measured. ${ }^{5,19}$

Wound contraction measurement: percentage wound contraction was assessed as follows.

$$
\begin{aligned}
& \text { Percentage Wound Contraction } \\
& =\frac{\text { wound sizeday } 0-\text { nth days of wound size }}{\text { Wound sizeday } 0} \times 100 \text { (2) }
\end{aligned}
$$

where $n=$ number of days, ie, $2^{\text {nd }}, 4^{\text {th }}, 6^{\text {th }}$, etc., until the wound in the treatment groups healed. 


\section{Epithelialization Period Measurement}

The removal of dead tissue without any residual raw wound was considered to be the end point of complete epithelialization, and the days required for this were taken to be the period of epithelialization.

\section{Incision Wound Model}

Mice were anesthetized and their fur removed as described in the excision wound model. Three centimeters long, linear-paravertebral incisions were made through the full thickness of the skin on either side of the spine, $1 \mathrm{~cm}$ from the middle of the spine.

The removed skin was held together and stitched using a chromic catgut ( $2 / 0$ metric-1/2 Circle) with a curved needle at $1 \mathrm{~cm}$ intervals, considered as Day 0 . From day 1, the ointments were applied as described in the section above. The ointments were applied once a day for 9 days. The sutures were removed on the 8th day post-wound. The tensile strength was then measured on the 10th day to measure the degree of healing. It was measured by continuous constant flow of water, taking into account the weight of the water needed to break the skin. Wound strength of groups treated with extract ointment was compared with that of the standard, simple ointment and untreated control. ${ }^{5}$ The percentage of tensile strength was calculated as follows;

Tensile strength of extract (\%)

Tensile strength (extract)

$$
=\frac{- \text { Tensile strength }(\text { simple ointment })}{\text { Tensile strength (simple ointment) }} \times 100 \text { (3) }
$$

Tensile strength of reference (\%)

Tensile strength (reference)

$$
=\frac{- \text { Tensile strength }(\text { simple ointment })}{\text { Tensile strength (simple ointment })} \times 100 \text { (4) }
$$

Tensile strength simple ointment (\%)

Tensile strength(simple ointment)

$$
=\frac{- \text { Tensile strength }(\text { left untreated })}{\text { Tensile strength(left untreated })} \times 100 \text { (5) }
$$

\section{Statistical Analysis}

Data analysis was performed using the Social Science Statistical Software (SPSS) version 25 for Windows (SPSS Inc, Chicago, IL). The results were expressed as mean \pm standard mean error (SEM) for each group. Statistical differences between groups were analyzed through a one-way variance analysis (ANOVA) using Tukey as a post-hoc test. Statistical significance was determined at $p<0.05$.

\section{Results}

\section{Yield of the Crude Extract}

From a total of $800 \mathrm{~g}$ dried and powdered leaves of Z. scabra macerated with $80 \%$ methanol for 72 hours twice, $50 \mathrm{~g}$ of dried crude extract was obtained. Hence, the percentage $(\% \mathrm{w} / \mathrm{w})$ yield of $Z$. scabra leaves extract was found to be $6.25 \%$.

\section{Acute Dermal Toxicity}

After 24 hours of application of $10 \%$ formulation of the extract, there was no dermal toxicity (inflammation, irritation, or redness) observed. There were no also signs and symptoms as well as mortality manifested when the animals were monitored for 48 hours and for 14 consecutive days of cage side observation.

\section{Wound Healing (Excision Model) Wound Contraction}

Starting from treatment day-4 to the end day-16 a significant reduction in the size of the excised wound was recorded (Table 1, Figure 1). The $5 \%$ and $10 \%(\mathrm{w} / \mathrm{w})$ $\mathrm{ZS}$ ointments, and $0.2 \% \mathrm{NF}$ ointment treated mice produced significant $(p<0.05)$ wound area reduction starting from day 4 , and highly significant $(p<0.01)$ differences were seen from day-10 onward in comparison with the simple ointment treated group. There was no significant difference in activity between $5 \%(\mathrm{w} / \mathrm{w})$ and $10 \%(\mathrm{w} / \mathrm{w})$ extracts. But, a higher rate of wound closure was observed with $10 \%(\mathrm{w} / \mathrm{w})$ ointment. $10 \%(\mathrm{w} / \mathrm{w}) \mathrm{ZS}$ extract showed comparable efficacy with standard drug after day-12. The maximum wound contraction rate was seen on the $14^{\text {th }}$ and $16^{\text {th }}$ day which was $96.6 \%$ and $99.3 \%$, respectively (Figure 2). Highly significant $(p<0.01)$ wound contraction was also obtained in the $0.2 \%(\mathrm{w} / \mathrm{w})$ NF ointment treated group from day-4 to day-10 onward as compared to the simple ointment treated group. The maximum rate of wound contraction for $0.2 \%(\mathrm{w} / \mathrm{w}) \mathrm{NF}$ ointment was seen on the $12^{\text {th }}, 14^{\text {th }}$, and $16^{\text {th }}$ day, which was $96.6 \%$, $99.3 \%$, and $99.99 \%$, respectively.

\section{Period of Epithelization}

$0.2 \%(\mathrm{w} / \mathrm{w}) \mathrm{NF}$ was shown as the fastest period of epithelization as compared to simple ointment, $5 \%$ and $10 \%(\mathrm{w} /$ w) ZS extract ointments, which was $11 \pm 0.24$ days (Table 2). There was no significant difference between $5 \%$ and 
$10 \%(\mathrm{w} / \mathrm{w}) \mathrm{ZS}$ ointments in the epithelialization period. However, both $5 \%$ and $10 \%(\mathrm{w} / \mathrm{w}) \mathrm{ZS}$ extract ointments elicited a significant $(p<0.05)$ shortening of the epithelialization period as compared to the simple ointment group.

\section{Incision Wound Model}

\section{Wound Breaking Strength (Tensile Strength)}

On the incision wound model, the extract ointments applied topically were found to be effective in increasing the tensile strength of the healing wound (Table 3). Both $5 \%$ and $10 \%$ extract ointments produced significantly $(p<0.05)$ higher tensile strength of the healing wound in comparison with the simple ointment and left untreated groups. Treatment with the standard agent $0.2 \%$ (w/w) NF also exhibited significantly $(p<0.01)$ increased tensile strength compared to both of these groups. The highest percent tensile strength $(72 \%)$ was shown in the $0.2 \%(\mathrm{w} / \mathrm{w}) \mathrm{NF}$ treated group.

\section{Discussion}

In Ethiopia, medicinal plants have been used traditionally for several years as topical and internal preparations to promote wound repairs. They have a great potential for wound healing by promoting the speed of wound healing with lower pain, discomfort, and scarring of the patient. ${ }^{20}$ The leaf of Z. scabra was traditionally claimed to be used for wound dressing and healing, and reducing body swelling. ${ }^{21}$ Therefore, in the present study we scientifically explored these traditional claims. The results of this study conclusively showed that the hydroalcoholic extract of Z. scabra significantly promotes wound healing in the excision wound model compared to the simple ointment treated group. In addition, the wound healing effect of $10 \%(\mathrm{w} / \mathrm{w})$ extract ointment was comparable with $0.2 \%$ w/w NF after day-12. On the $16^{\text {th }}$ day of treatment, significant healing with a percentage wound closure of $99.99 \%$ was observed in the $0.2 \% \mathrm{w} / \mathrm{w} \mathrm{NF}$ treatment group while it was $98 \%$ and $99.3 \%$ in the $5 \%$ and $10 \%$ (w/w) ZS treatment groups, respectively. Wound contraction, which contributes to wound closure, is expressed as a decrement in the percentage of the first wound size. ${ }^{22}$ During healing, contraction plays a crucial role as it decreases the dimension of the wound and hence shortens the healing time. Moreover, contraction reduces the extracellular matrix amount needed to repair the defect and helps re-epithelization by reducing the distance traveled by migrating keratinocytes. ${ }^{23}$ Another parameter used in this study was the epithelization period (time period at which epithelial reorganization takes place). The standard drug, $0.2 \%(\mathrm{w} / \mathrm{w}) \mathrm{NF}$, exhibited the fastest period of epithelization as compared to simple ointment, 5\% (w/ $\mathrm{w})$, and 10\% (w/w) ZS extract ointments which was 12 \pm 0.29 days. Both strengths of the extract ointment produced a significant $(p<0.05)$ difference of the epithelialization period as compared to the simple ointment group.

Increased rate of wound contraction and decrease in epithelialization period in mice treated with the extract may be attributed to the presence of phytoconstituents such as unsaturated sterols, triterpenoids, alkaloids, flavonoids, saponins, tannins, and phenolic compounds which are known to promote the wound healing process. $^{24}$ Flavonoids reduce the formation of

Table I Effect of $80 \%$ Methanol Leaf Extract of Z. scabra on Wound Contraction in Mice

\begin{tabular}{|c|c|c|c|c|c|c|c|c|}
\hline \multicolumn{9}{|c|}{ Wound Area in $\mathrm{mm}^{2}$ on Post-Wounding Day } \\
\hline Groups & Day 2 & Day 4 & Day 6 & Day 8 & Day 10 & Day 12 & Day 14 & Day 16 \\
\hline $\begin{array}{l}\text { Simple } \\
\text { ointment }\end{array}$ & $\begin{array}{l}289.51 \\
\pm 6.12\end{array}$ & $243.35 \pm 6.73$ & $|9| .86|2.4|$ & $\begin{array}{l}182.44 \\
\pm 14.10\end{array}$ & $136.9 \pm 4.32$ & $88.7 I \pm 6.87$ & $\begin{array}{l}55.58 \\
\pm 3.27\end{array}$ & $\begin{array}{l}30.30 \\
\pm 2.04\end{array}$ \\
\hline $5 \%(w / w) Z S$ & $\begin{array}{l}290.45 \\
\pm 16.96\end{array}$ & $235.28 \pm 11.05^{\mathrm{a} *}$ & $|80.4| \pm\left. 7.4\right|^{\mathrm{a} *}$ & $\begin{array}{l}|42.7| \\
\pm 16.40^{a} *\end{array}$ & $64.21 \pm 6.3^{\mathrm{a}} * *$ & $47.89 \pm 2.4^{\mathrm{a} * *}$ & $\begin{array}{l}28.26 \\
\pm 00^{\mathrm{a} * *}\end{array}$ & $\begin{array}{l}6.48 \\
\pm 0.82^{a * *}\end{array}$ \\
\hline $\begin{array}{l}10 \%(w / w) \\
Z S\end{array}$ & $\begin{array}{l}266.59 \\
\pm 14.85\end{array}$ & $227.17 \pm 8.41^{\mathrm{a} *}$ & $|58.4| \pm 4.55^{\mathrm{a} *}$ & $88.70 \pm 69^{\mathrm{a}} * *$ & $52.91 \pm 2.67^{\mathrm{a} * *}$ & $\begin{array}{l}22.34 \\
\pm 1.50^{\mathrm{a}} * *\end{array}$ & $\begin{array}{l}5.36 \\
\pm 1.34^{\mathrm{a} * *}\end{array}$ & $\begin{array}{l}\text { I.2 } \\
\pm\left. 0.3\right|^{\mathrm{a} * *}\end{array}$ \\
\hline $\begin{array}{l}0.2 \%(w / w) \\
N F\end{array}$ & $\begin{array}{l}266.9 \\
\pm 17.28\end{array}$ & $\begin{array}{l}|58.4| \\
\pm 4.55^{\mathrm{a} * * \mathrm{~b} * * c *}\end{array}$ & $\begin{array}{l}113.67 \\
\pm 8.43^{\mathrm{a} * * \mathrm{~b} * * \mathrm{c} *}\end{array}$ & $\begin{array}{l}75.52 \\
\pm 2.98^{\mathrm{a} * * \mathrm{~b} *}\end{array}$ & $\begin{array}{l}30.61 \\
\pm 3.57^{\mathrm{a} * * \mathrm{~b} * * c *}\end{array}$ & $\begin{array}{l}10.36 \\
\pm 1.4^{* a * * b *}\end{array}$ & $\begin{array}{l}2.2 \\
\pm 0.58^{\mathrm{a} * * \mathrm{~b} *}\end{array}$ & $\begin{array}{l}0.1 \\
\pm 0.19^{\mathrm{a} * * \mathrm{~b} *}\end{array}$ \\
\hline
\end{tabular}

Notes: Data are expressed as Mean $\pm S E M ;(\mathrm{n}=5$ animals in each group) and analyzed by one-way ANOVA followed by Tukey post-hoc test; numbers from $2-16$ indicate the day on which contraction rate measurement was taken, ${ }^{a}$ compared with simple ointment, ${ }^{b}$ compared with $5 \%$ extract, ${ }^{c}$ compared with $10 \%$ extract. ${ }^{*} p<0.05$, ${ }^{* *} p<0.01$. Abbreviations: NF, nitrofurazone; ZS, Zehneria scabra. 
Post-

wounding

Days

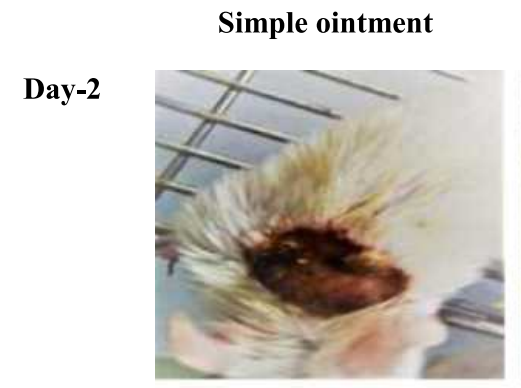

Day-4
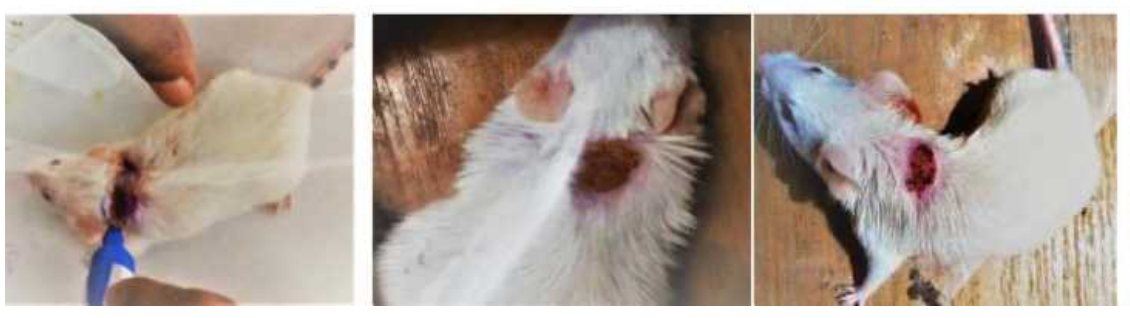

$5 \%(w / w)$ ZS extract

$10 \%(w / w) Z S$ extract

$0.2 \%(w / w) ~ N F$
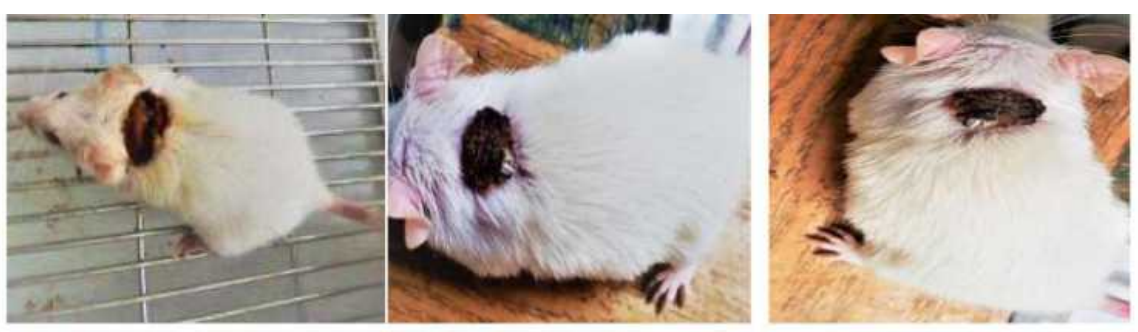

Figure I Wound contraction progress in simple ointment, $5 \% \mathrm{w} / \mathrm{w}$ and $10 \%(\mathrm{w} / \mathrm{w})$ ZS extract ointments, and $0.2 \% \mathrm{w} / \mathrm{w}$ NF treated groups across post-wounding days in excision model.

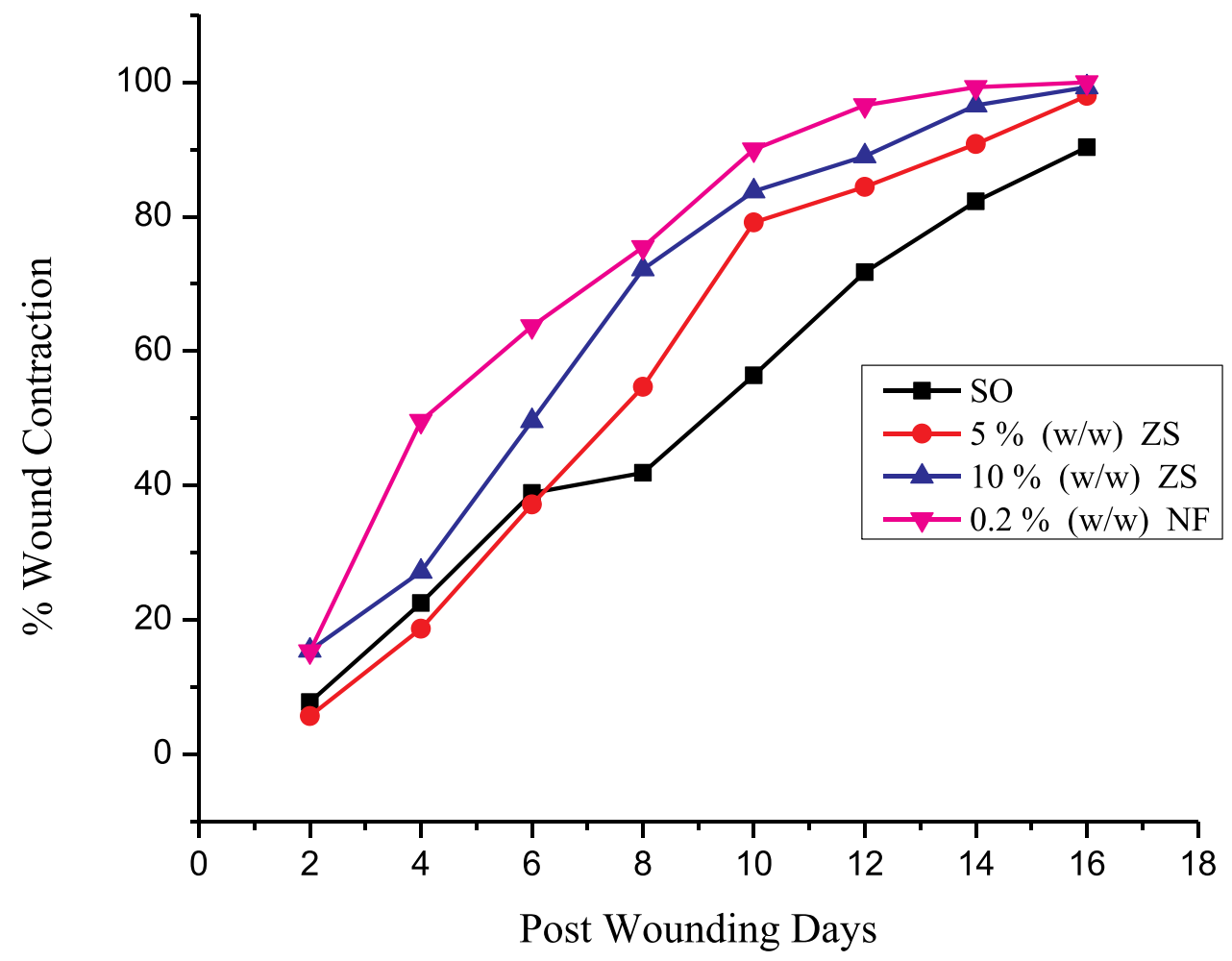

Figure 2 Percentage of wound area contraction effects of simple ointment, $5 \% \mathrm{w} / \mathrm{w}$ and $10 \% \mathrm{w} / \mathrm{w} \mathrm{ZS}$ extract ointments, and $0.2 \% \mathrm{w} / \mathrm{w}$ NF treatments in mice in excision model.

Abbreviations: SO, simple ointment; ZS, Zehneria scabra; NF, nitrofurazone. 
Table 2 Effect of Topical Application of $80 \%$ Methanol Leaf Extract of Z. scabra on Period of Epithelialization (Number of Days) Post-Wound Creation in Mice

\begin{tabular}{|l|l|}
\hline Groups & Period of Epithelization \\
\hline Simple ointment & $21.8 \pm 0.37$ \\
\hline $5 \%(w / w) ~ Z S$ & $15.59 \pm 0.31^{\mathrm{a}^{*}}$ \\
\hline $10 \%(w / w) Z S$ & $14.50 \pm 0.30^{\mathrm{a}^{*}}$ \\
\hline $0.2 \%(\mathrm{w} / \mathrm{w}) \mathrm{NF}$ & $12 \pm 0.2 \mathrm{a}^{\mathrm{a}^{*}}$ \\
\hline
\end{tabular}

Notes: Data are expressed as Mean $\pm S E M$; $(\mathrm{n}=5$ animals in each group) and analyzed by one-way ANOVA followed by Tukey post-hoc test, ${ }^{\mathrm{a}}$ compared with simple ointment, $* p<0.05$.

Abbreviations: NF, nitrofurazone; ZS, Zehneria scabra.

inflammatory metabolites by inhibiting both cyclooxygenase and lipoxygenase activities. ${ }^{25}$ Besides, flavonoids prevent neutrophil degranulation, which is a direct way to diminish the release of arachidonic acid by neutrophils and other immune cells which imparts to the wound healing activity of the extract. ${ }^{26}$ The astringent and antimicrobial properties of these phytochemicals might also be responsible for wound contraction and increased epithelialization rates. $^{27}$ Tannins are seen as active detoxifiers and inhibit bacterial growth. ${ }^{28}$ In vitro study on the leaf of methanolic extract of $Z$. scabra revealed activity against common wound pathogens such as $S$. aureus and $P$. aeruginosa which could support findings of this study. ${ }^{29}$

Further efficacy of Z. scabra extract in wound healing was demonstrated by tensile strength in incision wounds. The tensile strength of both $5 \%$ and $10 \%(\mathrm{w} /$ w) extract ointments treated groups was significantly higher $(p<0.01)$ compared to simple ointment treated and untreated groups. Tensile strength indicates how much the tissue being repaired resists tension and can indicate the quality of the tissue being repaired. The tensile strength of a wound depends mainly on an increase in the concentration of collagen and stabilization of fibers. ${ }^{30}$ A study revealed that phytochemical constituents identified in Z. scabra plant were directly responsible for antioxidant, antimicrobial, and antifungal activities through different mechanisms. ${ }^{27}$ For example, tannins promote wound healing by chelating free radicals and reactive oxygen species, reducing proteins due to their astringent effect, encouraging wound contraction, and increasing the formation of capillary vessels and fibroblasts. ${ }^{31}$
Table 3 Effect of the Ointment of $80 \%$ Methanol Leaf Extract of Z. scabra on Tensile Strength in Mice

\begin{tabular}{|l|l|l|}
\hline Groups & $\begin{array}{l}\text { Wound Breaking Strength } \\
(\mathbf{g})\end{array}$ & $\begin{array}{l}\text { \% Tensile } \\
\text { Strength }\end{array}$ \\
\hline Left untreated & $231 \pm 1.76$ & - \\
\hline $\begin{array}{l}\text { Simple } \\
\text { ointment }\end{array}$ & $236 \pm 1.87$ & $2 \%$ \\
\hline $5 \%(\mathrm{w} / \mathrm{w})$ ZS & $381 \pm 0.92^{\mathrm{a} * c *}$ & $62 \%$ \\
\hline $10 \%(\mathrm{w} / \mathrm{w})$ ZS & $390 \pm 1.12^{\mathrm{a} * c *}$ & $65 \%$ \\
\hline $\begin{array}{l}0.2 \%(\mathrm{w} / \mathrm{w}) \\
\text { NF }\end{array}$ & $407 \pm 1.87^{\mathrm{a} * * \mathrm{~b} * * * *}$ & $72 \%$ \\
\hline
\end{tabular}

Notes: Data are expressed as Mean $\pm S E M ;(\mathrm{n}=5)$ and analyzed by one way ANOVA followed by Tukey post-hoc test; ' ${ }^{\text {compared }}$ with simple ointment, bompared with $5 \%$ extract, "compared with left untreated, ${ }^{*} p<0.05, * * p<0.01$. Abbreviations: NF, nitrofurazone; ZS, Zehneria scabra.

On the other hand, flavonoids are responsible for reducing lipid peroxidation by preventing or slowing down cell necrosis and improving vascularity, which increases the viability of collagen fibrils by increasing circulation, preventing cell damage and promoting DNA synthesis. ${ }^{32,33}$

In conclusion, the different phases of wound repair; wound contraction, epithelization, and tensile strength were improved by ointments prepared from $80 \%$ methanol leaf extract of $Z$. scabra as compared to the simple ointment treated group. The findings of this study therefore support the traditional claims of the plant for wound treatment.

\section{Abbreviations}

NF, Nitrofurazone; ZS, Zehneria scabra.

\section{Disclosure}

The authors declare no competing interests.

\section{References}

1. Son YJ, John WT, Zhou Y, Mao W, Yim EK, Yoo HS. Biomaterials and controlled release strategy for epithelial wound healing. Biomater Sci. 2019;7(11):4444-4471.

2. Flangan M. The physiology of wound healing. $J$ Wound Care. 2000;9:299-300. doi:10.12968/jowc.2000.9.6.25994

3. Pecoraro RE, Reiber GE, Burgess EM. Pathways to diabetic limb amputation. Diabetes Care. 1990;13:513-521. doi:10.2337/ diacare.13.5.513

4. Muluye AB, Desta AG, Abate SK, et al. Anti-malarial activity of the root extract of Euphorbia abyssinica (Euphorbiaceae) against Plasmodium berghei infection in mice. Malar J. 2019;261.

5. Atkin L. Understanding methods of wound debridement. Br J Nurs. 2014;23(12):S10-S5. doi:10.12968/bjon.2014.23.sup12.S10 
6. DeLeo FR, Chambers HF. Reemergence of antibiotic-resistant Staphylococcus aureus in the genomics era. J Clin Invest. 2009;119 (9):2464-2474. doi:10.1172/JCI38226

7. García-Villén F, Faccendini A, Aguzzi C, et al. Montmorillonitenorfloxacin nanocomposite intended for healing of infected wounds. Int J Nanomedicine. 2019;14:5051-5060. doi:10.2147/IJN.S208713

8. Olsson M, Järbrink K, Divakar U, et al. The humanistic and economic burden of chronic wounds: a systematic review. Wound Repair Regen. 2019;27(1):114-125. doi:10.1111/wrr.12683

9. Hamdan S, Pastar I, Drakulich S, et al. Nanotechnology-driven therapeutic interventions in wound healing: potential uses and applications. ACS Cent Sci. 2017;3(3):163-175. doi:10.1021/ acscentsci.6b00371

10. Getaneh S, Girma Z. An ethnobotanical study of medicinal plants in Debre Libanos Wereda, central Ethiopia. Afr J Plant Sci. 2014;8:366-379. doi:10.5897/AJPS2013.1041

11. Abew B, Sahile S, Moges F. In vitro antibacterial activity of leaf extracts of Zehneria scabra and Ricinus communis against Escherichia coli and methicillin resistance Staphylococcus aureus. Asian Pac J Trop Biomed. 2014;4(10):816-820. doi:10.12980/ APJTB.4.201414B16

12. Tadesse WT, Hailu AE, Gurmu AE, et al. Experimental assessment of antidiarrheal and antisecretory activity of $80 \%$ methanolic leaf extract of Zehneria scabra in mice. BMC Complement Altern Med. 2014;14:460. doi:10.1186/1472-6882-14-460

13. Tesfaye WH, Alamneh EA. In vivo antimalarial activity of the crude extract and solvent fractions of the leaves of Zehenria scabra (Cucurbitaceae) against Plasmodium berghei in mice. J Med Plant Res. 2014;8(42):1230-1236.

14. Belay R. Evaluation of the Anti-Inflammatory Activities of $70 \%$ Ethanol Leaves Extract and Solvent Fractions of Zehneria Scabra (Lf) Sond (Cucurbitaceae) in Rodents. Department of Pharmacology, School of Medicine, College of Health Sciences; 2016.

15. Care IoLARCo, Animals UoL. Guide for the Care and Use of Laboratory Animals: US Department of Health and Human Services. National Public Health Service; 1986.

16. Morton J, Malone M. Evaluation of vulneray activity by an open wound procedure in rats. Arch Int Pharmacodyn Ther. 1972;196 (1): 117 .

17. Tredget EE, Nedelec B, Scott PG, Ghahary A. Hypertrophic scars, keloids, and contractures: the cellular and molecular basis for therapy. Clin North Am. 1997;77(3):701-730. doi:10.1016/S00396109(05)70576-4

18. OECD 404 Guidelines for the Testing of Chemicals. Acute dermal irritation/corrosion. OECD Guidel Test Chem Sect Heal Eff. 2015; (July 28th): 1-8.

19. Acton C. Holistic management of chronic wound pain. Wounds $U K$. 2007;3(1):61.
20. Fikru A, Makonnen E, Eguale T, Debella A, Mekonnen GA. Evaluation of in vivo wound healing activity of methanol extract of Achyranthes aspera. J Ethnopharmacol. 2012;143(2):469-474. doi:10.1016/j.jep.2012.06.049

21. Muthu C, Ayyanar M, Raja N, Ignacimuthu S. Medicinal plants used by traditional healers in Kancheepuram District of Tamil Nadu, India. J Ethnobiol Ethnomed. 2006;2(1):1-10. doi:10.1186/1746-4269-2-1

22. Collier M. Recognition and management of wound infections. World Wide Wounds. 2004;7:8-14.

23. Mukherjee PK, Verpoorte R, Suresh B. Evaluation of in-vivo wound healing activity of Hypericum patulum (Family: hypericaceae) leaf extract on different wound model in rats. J Ethnopharmacol. 2000;70 (3):315-321. doi:10.1016/S0378-8741(99)00172-5

24. Mulisa E, Asres K, Engidawork E. Evaluation of wound healing and anti-inflammatory activity of the rhizomes of Rumex abyssinicus J. (Polygonaceae) in mice. BMC Complement Alter Med. 2015;15 (1):341. doi:10.1186/s12906-015-0878-y

25. Robert JN, Els N, Danny EC, Petra GB, Klaske N, Paul L. Flavonoids: a review of probable mechanisms of action and potential applications. Am J Clin Nutr. 2001;74:418-425. doi:10.1093/ajcn/ 74.4 .418

26. Akele B. Inivo anti-inflammatory and anti-noceceptive activities of arerial part extracts of Zehneria scabra. IJPIR. 2012;2(4):479-484.

27. Mekonnen NA, Atnafie AS, Atta WM. Evaluation of the anti-inflammatory activities of $70 \%$ ethanol leaves extract and solvent fractions of Zehneria scabra (Lf) Sond (Cucurbitaceae) in rodents. Evid Based Compl Alt. 2020;2020:11.

28. Du Toit K, Drewes SE, Bodenstein J. The chemical structures, plant origins, ethnobotany and biological activities of homoisoflavanones. Nat Prod Res. 2010;24(5):457-490. doi:10.1080/ 14786410903335174

29. Smith AH, Zoetendal E, Mackie RI. Bacterial mechanisms to overcome inhibitory effects of dietary tannins. Microb. 2005;50 (2):197-205.

30. Tegenu G. Antimicrobial activity of solvent-extracts of Cucumis ficifolius and Zehneria scabra on some test microorganisms: M. sc Thesis. Addis Ababa. 2011.

31. Basu S, Shivhare U. Rheological, textural, micro-structural and sensory properties of mango jam. J Food Eng. 2010;100(2):357-365. doi:10.1016/j.jfoodeng.2010.04.022

32. Odukoya OA, Sofidiya MO, Samuel AT, Ajose I, Onalo M, Shuaib B. Documentation of wound healing plants in Lagos-Nigeria: inhibition of lipid peroxidation as in-vivo prognostic biomarkers of activity. Ann Biol Res. 2012;3(4):1683-1789.

33. Chung S, Kim HJ, Choi HK, Park JH, Hwang JT. Comparative study of the effects of diosmin and diosmetin on fat accumulation, dyslipidemia, and glucose intolerance in mice fed a high-fat high-sucrose diet. Food Sci Nutr. 2020;8(11):5976-5984. doi:10.1002/fsn3.1883

\section{Publish your work in this journal}

The Journal of Experimental Pharmacology is an international, peerreviewed, open access journal publishing original research, reports, reviews and commentaries on all areas of laboratory and experimental pharmacology. The manuscript management system is completely online and includes a very quick and fair peer-review system. Visit http://www.dovepress.com/testimonials.php to read real quotes from published authors. 